\title{
Scour prediction in non-uniform soils: undrained shear strength and erodibility
}

\author{
JM Harris ${ }^{1}$ and RJS Whitehouse ${ }^{1}$
}

${ }^{1}$ HR Wallingford, Howbery Park, Wallingford, Oxfordshire OX10 8BA, UK

Published in the Scour and Erosion, Proc. 7th Int. Conf. on Scour and Erosion, The University of Western Australia, 2-4 December 2014 (2015)

\section{Abstract}

Scour development in non-uniform soils is still an area of great uncertainty and remains a challenge for designing structurally efficient and effective foundations in the marine environment. Scour risk in cohesive soils is made more uncertain by effects such as weathering and time-scale to scour. For large volume installation of foundations such as those related to offshore wind farm developments there is a limit to the amount of detailed geotechnical information that can be collected as part of the project. Therefore, reliance in data such as undrained shear strength, derived from cone penetration tests, supplemented with borehole data collected at a limited number of sites across the wind farm and laboratory analysis of soil samples becomes the principal source of geotechnical information. Hence, the question arises as to whether the undrained shear strength be used as a proxy for the erodibility of a soil as proposed in the approach of Annandale (1995). This paper will present evidence from both field and laboratory measurements of undrained shear strength and scour potential to test the hypothesis of undrained shear strength as a proxy for scour.

\section{Introduction}

Scour is a hydrodynamic process related to the movement of the seabed sediment as a result of the flow of water past and away from a structure. The soil conditions are described by geotechnical parameters, therefore, scour is also of a geotechnical nature as it relates to the reduction in ground level around a structure. Marine soils are often variable in their makeup, and consist of a range of sediments, including sands, gravels, silts and clays. Van Ledden et al. (2004) defined six types of sediment bed based on sediment particle size distribution and the remolded shear strength as a measure of cohesion.

The distribution of a given soil type within a sample will be site specific and will also vary with depth below the seabed. Understanding of how the non-uniformity and layering of a soil and its variation with depth impacts scour development around a structure is still limited and is not routinely accounted for in design.

The terms clay and mud are often incorrectly used interchangeably in sediment transport. Mud is typically defined as a mixture of water, clay and silt, and also includes organic material and sometimes gas (e.g. hydrogen sulphide resulting from organic decomposition). Mud is generically classified as particle sizes of less than $63 \mu \mathrm{m}$, which includes silt. Whereas clays have a plate-like structure, and generally have a diameter less than $2 \mu \mathrm{m}$. It should be noted that the United States Department of Agriculture classifies silt as less than $50 \mu \mathrm{m}$, and other countries have their own particle size classifications. 
Granular classification enables scientists and engineers to assess the nature of soil behaviour, i.e. cohesive, granular or mixed, which has important implications for the mechanical and erosion properties of a sediment (Whitehouse et al., 2000; Winterwerp and van Kesteren, 2004). The degree of cohesion increases with the fraction of clay minerals within the sediment, and starts to become significant when the sediment contains more than $5-10 \%$ of clay by weight. The most important types of clay minerals are: kaolinite, chlorite, montmorillonite, and illite.

The prediction of scour in cohesive or multi-modal soils is more complex. Typically the scour process is much slower; as a result the effect of scour is very much dependent on the period of time that the structure will remain at the site. Annandale (1995) proposed an approach to estimating the erosion potential of complex soils through the use of the stream power parameter, $P$, and its relationship to the ability of the soil to resist scour, defined through an Erodibility Index, $K$. The Erodibility Index provides a measure of the in-situ strength of the material, whilst the stream power provides a measure of the rate of energy dissipation in the near-bed region due to hydrodynamic forces. If $P$ exceeds the erosion threshold then scouring will occur.

\section{Erodibility}

Soil mechanics testing provides workable definitions of the complete spectrum of soil types from pure cohesionless sands to clays. Therefore a variety of soil parameter definitions have been prescribed and test procedures defined to help the engineer assess the performance of foundations (e.g. Terzaghi et al., 1996). These measures of soil properties have also been used in an attempt to produce correlations between the hydraulic behaviour of the soil (i.e. threshold for erosion and erosion rate) and the properties of the bed such as bulk density and shear strength. This is an important parameter in the assessment of scour hazard.

The erodibility of clay soils has been evaluated in terms of direct geotechnical measures of bed strength. However, the analogy between the force required to strip the surface layers of a soil through the action of flowing water and the force required to shear the bed using a shear vane (which measures the torque force required to rotate a vane of a given shape and size) is not that clear. Individual studies have demonstrated that a reasonable correlation exists between the two measures (e.g. Kamphuis and Hall, 1983). They found that the value of shear stress required for erosion increased with unconfined compressive strength, vane shear strength, plasticity index, and clay content of the soil, and with increasing pre-consolidation pressure. The results of tests on a consolidated cohesive sediment (clay) showed the variation of threshold shear stress for erosion with the first two parameters was linear.

Kamphuis and Hall found the ability of a cohesive soil to resist erosion increased with clay content and plasticity index. One notable conclusion was, for the clay tested in their study, if the consolidation pressure was greater than approximately $200 \mathrm{kPa}$ then the soil was considered safe from erosion under "normally expected, naturally occurring flow conditions".

\section{Scour in cohesive soils and clays}

The principal body of work on scour in cohesive soils and clays is related to scouring around bridge piers. Molinas et al. (1999) presented results from a study conducted using montmorillonitic cohesive soils. They noted a distinction between pier scour occurring in unsaturated compacted soils compared with that occurring in saturated soils. In general they found that the local scour depth decreased as the initial water content decreases and increased as the Froude number $\left(F_{r}\right)$ increases (Figure 1). They also state that the 
side slopes of the local scour holes formed in the tests were much steeper than those encountered in noncohesive soils, although this may be a short-term effect.

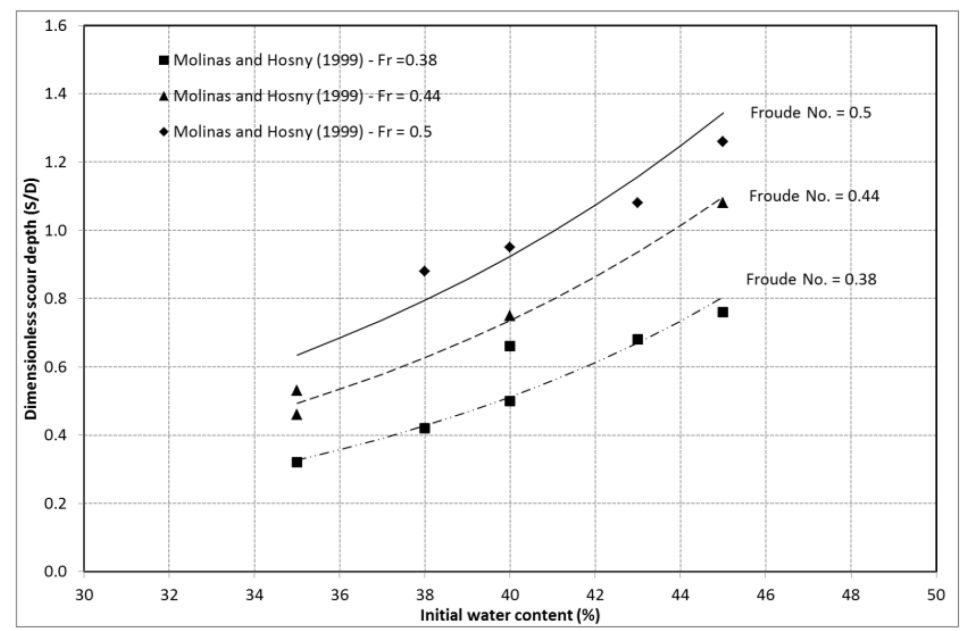

Figure 1. Effect of initial water content on local pier scour for a saturated cohesive soil under different approach flow conditions (after Molinas et al., 1999)

Briaud et al. (1999) proposed an approach to predicting the scour depth and rate of scour in cohesive soils around a cylindrical bridge pier. The SRICOS method (Scour Rate In COhesive Soils) involved taking site specific samples and testing them in an Erosion Function Apparatus to obtain the rate of scour against the applied hydraulic shear stress, and combining this information with the maximum shear stress prior to scour developing. Having undertaken these steps the maximum scour depth for the given pier structure could be determined and then a hyperbolic function developed to describe the scour depth with time curve. The predictions obtained using this method were compared against measurements from 42 flume experiments.

Briaud et al. proposed a simple relationship for the maximum scour depth, $S_{\max }$, based on the pier Reynolds number $R_{D}$ :

$S_{\max }=0.00018 R_{D}^{0.635}$

where,

$R_{D}=\frac{V D}{v}$

and $V$ is the mean flow velocity, $D$ is the pier diameter and $v$ is the kinematic viscosity. The formula is similar to that proposed by Shen et al. (1969) for scour in non-cohesive soils.

$S_{e}=0.000223 R_{D}^{0.619}$

where $S_{e}$ is the equilibrium scour depth. Comparing Eqns. (1) and (3) suggests the equilibrium scour in cohesive soils and non-cohesive soils is similar.

Ting et al. (2001) reported on a series of experiments in the laboratory to study local scour at cylindrical piers in clay. They compared their results with experimental data for local scour in sand and investigated the effects of Reynolds number, Froude number and approach flow depth on the local scour depth. They compared their results with predictions obtained using the approach outlined in Richardson and Davis 
(1995). The results indicated that although the rates of scour in clay were much slower than in sand, the equilibrium scour depth was similar to that obtained in sand (confirming the conclusion regarding Eqns. (1) and (3) above). Ting et al. also noted that the shape of the scour hole correlated with the pier Reynolds number, with the scour developing relatively uniformly around the pier at low pier Reynolds numbers. At higher pier Reynolds numbers, the scour holes developed mainly behind the piers with much less scour forming in front of the piers.

For the test conditions run, Ting et al. did not find any noticeable effect of Froude number and approach flow depth on scour depth. The experiments were carried out using five different sediment types, three clays (porcelain, armstone and bentonite) and two sands (fine, $d_{50}=0.14 \mathrm{~mm}$; and medium, $d_{50}=0.60 \mathrm{~mm}$ ). Froude numbers were in the range 0.1 to 0.42 and the ratio of the approach flow depth to the pier diameter varied between 1.43 and 16 . Seven scour tests were carried out using the two sands for comparison purposes.

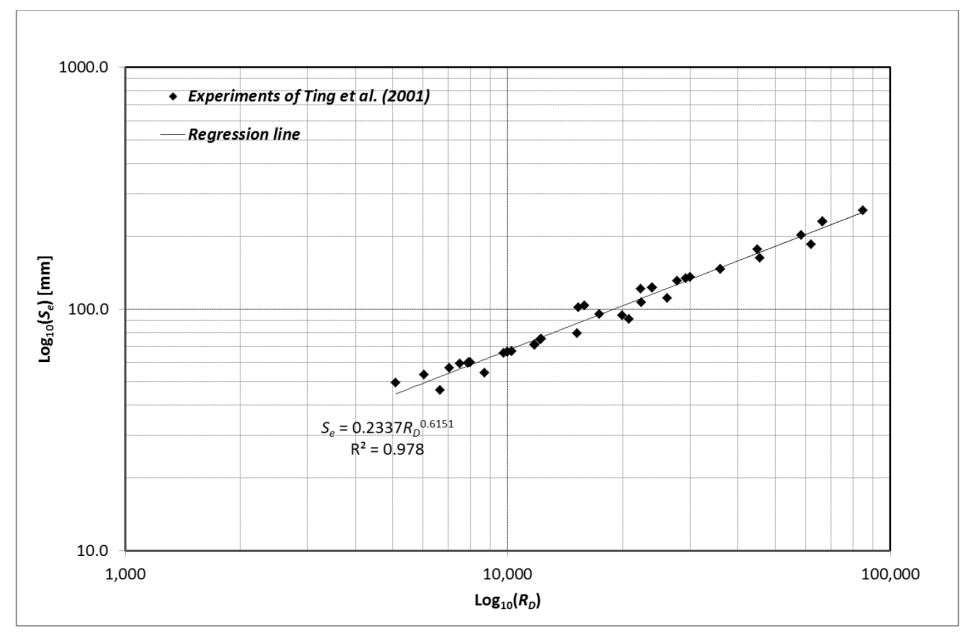

Figure 2. Variation of equilibrium scour depth with pier Reynolds number for clay and sand (after Ting et al., 2001)

The results as presented in Figure 2 show remarkable agreement with the results of Shen et al. (1969) (compare with Eqn. (2) - the leading coefficient in Ting et al. relates to scour depth in $\mathrm{mm}$ ). The results of Shen et al. were valid for clearwater scour conditions only, as they found that in the non-cohesive soils that they used under live-bed conditions the sediment transport into the scour hole resulted in a decrease in scour depth. In cohesive soils where the eroded particles remain in suspension the scouring process essentially remains within the clearwater regime and the equilibrium scour depth increases with pier Reynolds number. Whether this approach is valid for cohesive marine soils is more difficult to determine as stiff glacial tills once eroded may release both granular sediment, silts and clays and some bedload transport may occur.

Ansari et al. (2002) investigated the influence of cohesive sediments on scour around bridge piers under steady flows. Ansari et al. proposed a numerical model to calculate the temporal variation of scour depth in cohesive sediments based on the characteristics of the horseshoe vortex. The shear stress under the horseshoe vortex was determined through consideration of the initial magnitude of the principal vortex tube, which Ansari et al. proposed at the sides of the pier was 0.316 times that formed at the nose. Their model was compared against laboratory data. It is interesting to note that the results of the comparison are variable, with some test results comparing very favourably with the model, whilst in other tests the model fails to 
predict the initial onset of scouring well, but gives a reasonable fit towards the peak values. The authors attribute the model's poor fit at the start of the tests to dominance of scouring at the sides of the pier initially, whilst later in the tests scour development at the nose of the pier is dominant. Therefore, the model would appear to be better able to predict the maximum scour depth than the earlier stages of scour development.

Rambabu et al. (2003) presented results from a limited number of tests using three different model cylinders with diameters of $50 \mathrm{~mm}, 90 \mathrm{~mm}$ and $110 \mathrm{~mm}$ embedded in a silty clay soil. The tests were of short duration and a hyperbolic function was used to obtain the theoretical maximum scour depth.

Rambabu et al. concluded that the equilibrium scour depth decreased with increasing averaged undrained shear strength and increased with increasing Reynolds number. Based on their experimental results they proposed a general relationship for scour in terms of Froude number $F_{r},=U_{d} /(g h)^{0.5}$ pile Reynolds number, $R_{D}$, and soil strength parameter as presented in Eqn. 4 below.

$$
S_{e}=D F_{r}^{0.641} R_{D}^{0.640}\left(\frac{C_{u}}{\gamma h}\right)^{-0.976}
$$

Where $C_{u}$ is the undrained shear strength of the soil; $\gamma$ is the unit weight of the soil; $U_{c}$ is the current velocity; $g$ is the gravitational acceleration, and $h$ is the flow depth.

Debnath and Chaudhuri (2010) undertook experiments using clay and clay-sand sediment mixtures and investigated the effects of clay content, water content, Froude number and applied shear stress on the equilibrium scour depth and associated scour hole geometry as well the scour development through time.

From their studies Debnath and Chaudhuri concluded that for the soils tested with a water content less than $24 \%$ the equilibrium scour depth decreased with increasing clay content. For water content greater than 27 $\%$ and increasing clay content they found that the equilibrium scour depth decreased up to $50 \%$ to $70 \%$ clay content and then increased with higher clay content beyond these limits (Figure 3). This point of inflection was a function of the water content of the clay-sand soil mixture.

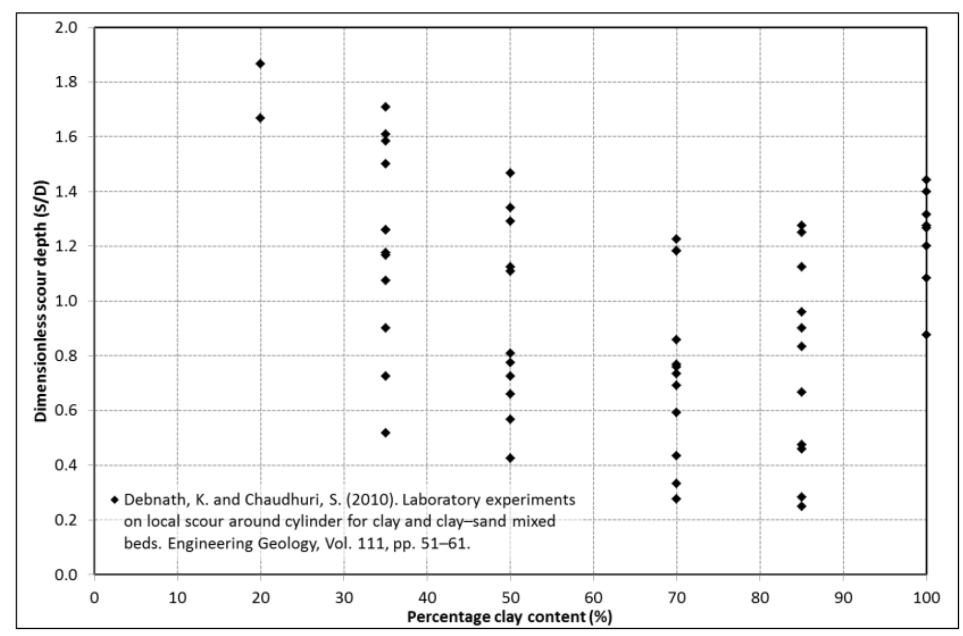

Figure 3. Variation in dimensionless scour depth against percentage clay content in the sample (after Debnath and Chaudhuri, 2010) 
Debnath and Chaudhuri (2010) also noted the shear strength obtained using a shear vane was an important parameter for describing the equilibrium scour depth in the clay-sand mixtures tested. With respect to the formation of the scour, it started at the sides of the cylinder and then propagated downstream in all cases. Under lower shear stress conditions the maximum scour depth was located downstream of the cylinder, whilst at intermediate conditions the scour formed simultaneously at both the upstream and downstream sides of the cylinder. At higher values of shear stress the scour development upstream was greater and faster than that at the downstream side of the cylinder. Debnath and Chaudhuri do not give corresponding flow conditions and describe the results as relative to the different soil samples and corresponding geotechnical characteristics of the samples.

Debnath and Chaudhuri (2012) extended their earlier studies investigating local scour around non-cylindrical piers in clay-sand sediment mixtures. Round nosed, square and rectangular piers were chosen, with identical widths to the diameter of the cylinder used in the previous tests $(0.12 \mathrm{~m})$. They examined the effect of clay content, water content and shear strength of the clay-sand sediment mixtures on the scouring process as well as the time development and scour hole geometry.

For the round nosed pier the equilibrium scour depths were typically lower than those obtained for the cylindrical pier, whilst being greater for the square and rectangular shaped structures. They noted once again that the vane shear strength is a key parameter in describing the equilibrium scour depth. Debnath and Chaudhuri (2012) noted three different modes of erosion: Particle-by-particle; in flocs, and "chunk-by-chunk". A similar observation was made by Kothyari et al. (2014). For the particular tests conducted the chunks were of the order of 2 to $5 \mathrm{~mm}$.

Kothyari et al. (2014) investigated scour in the wake region of cylindrical piers using two different sediment types: fine gravel mixed with clay in proportions ranging between $20 \%$ and $60 \%$ by weight; and fine gravel and fine sand in equal proportion by weight mixed with clay in proportions ranging between $20 \%$ and $60 \%$ by weight. They used a range of moisture contents, dry densities, clay content, void ratios and unconfined compressive strengths in the soils tested.

Kothyari et al. noted in their tests that scour holes formed in their tests were significantly different than those formed in non-cohesive sediments and, in a similar fashion to earlier studies (e.g. Ting et al., 2001), significant scouring took place on the downstream side of the piers with, in some cases, negligible scouring taking place at the upstream side. The maximum duration of the tests was about 15.5 hours, therefore, in the longer-term (weeks, months, years) it is likely that the scour pattern will continue to evolve, based on experience from field measurements, however, their results support previous studies which showed scour development in cohesive soils to form at the downstream side of the pier with the maximum scour depth often forming behind the pier.

At lower percentages of clay content $(\leq 30 \%)$ the scour took place on a particle by particle basis, whilst at higher percentages of clay content the sediment scoured in the form of thick flakes. It was also noted that with higher values of unconfined compressive strength and higher percentages of clay content $(>40 \%)$ the sediment scoured in the form of "chunks". This "peeling away" of sediment has been observed by other researchers (Whitehouse et al., 2000). Kothyari et al. also concluded that the clay content and unconfined compressive strength of the soil were significant factors in affecting the scour depth in the wake region of the pier. They do not comment on the effect of the granular material within the soil and as to whether its release in the scouring process led to any weathering/ abrasion of the surface. 


\section{Erosion testing of marine soils}

Lefebvre et al. (1986) undertook a series of tests on three eastern Canadian marine clays, investigating soil specimens with an intact structure, specimens remolded and reconsolidated and specimens destructured by consolidation. They found that the high resistance to erosion of the natural intact marine clay is primarily in response to the relatively strong links between clay particles. Whilst the clay structure remains intact the pore water - soil structure does not have a significant effect since the erodibility of the soil at the particle level is controlled by the natural structure of the soil. However, remolding and reconsolidation of the samples led to high erodibility of some samples, whilst other samples remained resistant to erosion. One of the controlling factors was the salinity of the pore water - soil structure.

Consolidation of intact specimens beyond the pre-consolidation pressure was found, in some instances, to lead to a significant increase in the erodibility of the soil.

Kamphuis et al. (1990) undertook erosion tests on four natural intact cohesive soils obtained from Ontario, Canada, using a laboratory flume. The soils were extracted from the field using a rectangular cutting frame ( $0.6 \mathrm{~m}$ long by $0.15 \mathrm{~m}$ wide and $0.1 \mathrm{~m}$ deep). The sample and cutting frame were removed together and waxed. Prior to testing the sample was trimmed flush with the cutting frame and both the frame and sample were placed in the flume.

In their tests Kamphuis et al. found that erosion of the samples was controlled by the discontinuities present in the sample rather than the geotechnical properties with the inception of erosion beginning between a shear stress of 0 and $6 \mathrm{~Pa}$. Erosion of the sample by sand suspension appeared to start once the sand particles became mobile at around a shear stress of 0 to $2 \mathrm{~Pa}$. Erosion at $0 \mathrm{~Pa}$ suggests turbulent fluctuations play a role at very low time-averaged stresses.

The sand suspension could increase erosion of the sample by up to five times beyond that for the clearwater case and it was concluded that erosion of cohesive soils may be controlled by the size of the particles rather than the properties of the cohesive soils in environments were the flows contain solid particles.

In fact, erosion testing of marine soils in the laboratory is generally considered to be the most reliable approach to assessing field performance. There are number of suitable in situ erosion equipment that can be used to determine the erosion threshold and erosion rate of the soil. These devices can be applied to barrel core or box core samples obtained from site. A review of erosion devices has been made by Black and Paterson (1997) and Annandale (2006). Devices of this kind include ISIS and SedErode (Williamson and Ockenden, 1996; Mitchener et al., 1996), the Erosion Function Apparatus (EFA) (Briaud et al., 2001) and the Simulator of Erosion Rate Function (SERF) device (Jiang et al., 2004). Such devices can take a section of core or alternatively use a remoulded sample. The different approaches to erodibility testing and their application has been analysed by Whitehouse and Harris (2014). Remolding effects that takes place during foundation installation may be significant in determining the soil strength, and, therefore, the resistance to erosion.

Measurements can be carried out on sediment samples from different levels in the seabed to determine the difference in erodibility with depth. An estimate of the threshold for erosion and the rate of erosion can be determined from the analysis of the time-series data as material is removed from the surface of the sample. 


\section{Abrasion of cohesive soils}

Very few studies have been conducted to assess the effect of abrasion on the erosion of consolidated clay soils. The role of granular material in erosion of a consolidated cohesive bed has been studied by Kamphuis (1983). Two modes of erosion were identified, "sand blasting" caused by impact of individual sand particles moving by saltation and "milling" as a result of sand particles moving as a bed layer. The impact induced erosion resulted in more severe erosion. The study used a site specific soil and only a limited number of tests (six) were conducted, but a number of general conclusions can still be drawn from the results. A fluid containing sand particles will cause erosion of a consolidated cohesive bed at much lower fluid velocities (or shear stresses) than if the fluid was clear. A maximum (local) erosion rate of $2.3 \mathrm{~mm} /$ hour was obtained in one of the tests, but more typically the erosion rate was of the order of $1 \mathrm{~mm} / \mathrm{hour}$. Longer-term rates of bed degradation of $0.2 \mathrm{~mm} /$ hour for consolidated clay (consolidated to $345 \mathrm{kPa}$ ) were obtained for velocities in the range 0.6 to $2.2 \mathrm{~m} / \mathrm{s}$ at $3 \mathrm{~mm}$ above the bed.

\section{Evidence from field data}

The evidence database on scour, created primarily from monitoring data collected at UK Offshore Wind Farms (OWF), relates to monopile foundations in different sediment and hydrodynamic environments. Despite the large number of wind farm developments the evidence base related to cohesive soils in the marine environment requires further investigation.

Jiang et al. (2004) presented observations of scour development in firm clay adjacent to an oil-unloading terminal in a tidal river. They noted a scour depth of $5 \mathrm{~m}$, indicating that in some environments stiff clay may need to be treated as a scour hazard.

Some of the early analysis and reviews of the monitoring data from Round 1 and Round 2 offshore wind farm sites in the UK are presented in DECC (2008), COWRIE (2010), Whitehouse et al. (2010) and Harris et al. (2011). Three of the wind farm sites where monitoring data was available for seabed sediments influenced or underlain by clay are Barrow, Kentish Flats and North Hoyle. In all three cases the foundation consists of a circular monopile.

The characteristics of the three sites are presented in Table 1 and the scour is described below.

\subsection{Barrow OWF}

Barrow OWF is a Round 1 wind farm consisting of $30,4.75 \mathrm{~m}$ diameter monopile foundations, situated about $8 \mathrm{~km}$ southwest of Walney Island in the Irish Sea. Scour was measured at thirteen of the foundations over a number of years. The first scour survey was undertaken in 2005 and showed that in the glacial till to the eastern part of the site, low scour depths (up to $S / D=0.04$ ) were measured. There was some indication that scour depths in the glacial till increased slowly with time following installation (DECC, 2008). Depressions from the spudcan footings of the jack-up barge used for installation were also visible in the seabed. 
Table 1. Site characteristics

\begin{tabular}{|c|c|c|c|c|c|c|c|c|c|c|}
\hline \multirow[t]{2}{*}{ Site } & \multirow[t]{2}{*}{ Description } & \multirow[t]{2}{*}{ Seabed sediment } & $D$ & SP & $\begin{array}{c}h \\
\text { (LAT) }\end{array}$ & $\begin{array}{c}\text { MTL } \\
\text { above } \\
\text { LAT }\end{array}$ & $\begin{array}{l}\text { Tidal } \\
\text { range }\end{array}$ & $\begin{array}{l}\text { Tidal range } \\
\text { Neap (n); } \\
\text { Spring (s) }\end{array}$ & $U_{p}$ & $\begin{array}{c}\text { Annual } \\
H_{s}\end{array}$ \\
\hline & & & $(\mathrm{m})$ & & $(\mathrm{m})$ & $(\mathrm{m})$ & $(\mathrm{m})$ & $(\mathrm{m})$ & $(\mathrm{m} / \mathrm{s})$ & $(\mathrm{m})$ \\
\hline Barrow OWF & $\begin{array}{l}\text { Open seabed, northwest } \\
\text { coast of England: exposed } \\
\text { to waves, moderate } \\
\text { currents, sand and clay, } \\
\text { stable seabed environment, } \\
\text { moderate water depth. }\end{array}$ & $\begin{array}{l}\text { Fine SAND to } \\
\text { muddy SAND, } \\
\text { some GRAVELS } \\
\text { overlying CLAY; } \\
\text { exposed CLAY }\end{array}$ & 4.75 & No & $\begin{array}{c}12 \text { to } \\
18\end{array}$ & 5.1 & $\begin{array}{l}4.1(n) \\
8.2(s)\end{array}$ & 0.8 & 4.9 & 4.75 \\
\hline Kentish Flats OWF & $\begin{array}{l}\text { Open seabed Thames } \\
\text { Estuary, England: exposed } \\
\text { to waves, moderate } \\
\text { currents, sand and clay, } \\
\text { stable seabed environment, } \\
\text { very shallow water. }\end{array}$ & $\begin{array}{l}\text { Fine SAND; infilled } \\
\text { paleo-channel with } \\
\text { CLAYS and } \\
\text { SANDS; CLAY } \\
\text { near surface or } \\
\text { exposed }\end{array}$ & 5 & No & 3 to 5 & 2.74 & $\begin{array}{l}2.9(n) \\
4.7(s)\end{array}$ & 0.9 & $3.3^{*}$ & 5 \\
\hline North Hoyle OWF & $\begin{array}{l}\text { Open seabed, North Wales: } \\
\text { exposed to waves, } \\
\text { moderate currents, } \\
\text { gravel/sandy gravel, stable } \\
\text { seabed environment, } \\
\text { moderate water depth. }\end{array}$ & $\begin{array}{l}\text { Gravelly medium } \\
\text { SAND or sandy } \\
\text { GRAVEL overlying } \\
\text { CLAY }\end{array}$ & 4 & No & 6 to 12 & 5.15 & $\begin{array}{l}4.1(n) \\
6.1(s)\end{array}$ & 1.17 & 4.9 & 4 \\
\hline
\end{tabular}

Where: $D$ is the monopile diameter; SP is scour protection; $h$ is water depth; MTL is Mean Tide Level; $U_{p}$ is peak current speed; $H_{s}$ is significant wave height, and ${ }^{*}$ is depth limited at low water levels 
All thirty foundations were re-surveyed in September 2006. In those areas covered with a thin veneer of sand the scour depths were limited by the thickness of that layer to scour depths of up to and around $0.5 \mathrm{~m}$ or $0.1 D$ in clay sites. Figure 4 shows one of the clay sites with a shallow scour hole of up to $1.25 \mathrm{~m}$ in depth.

The key parameters which determine the amount of scour are the composition and thickness of the surficial and sub-surface sediment layers as well as the prevailing hydrodynamic conditions. The monitoring data from Barrow OWF demonstrated that for the clay dominated sites scour had been restricted by the thickness of the surficial layer and the resistant properties of the underlying soils. The depth limited cases generally lay to the east of the site where the seabed consisted of glacial till.

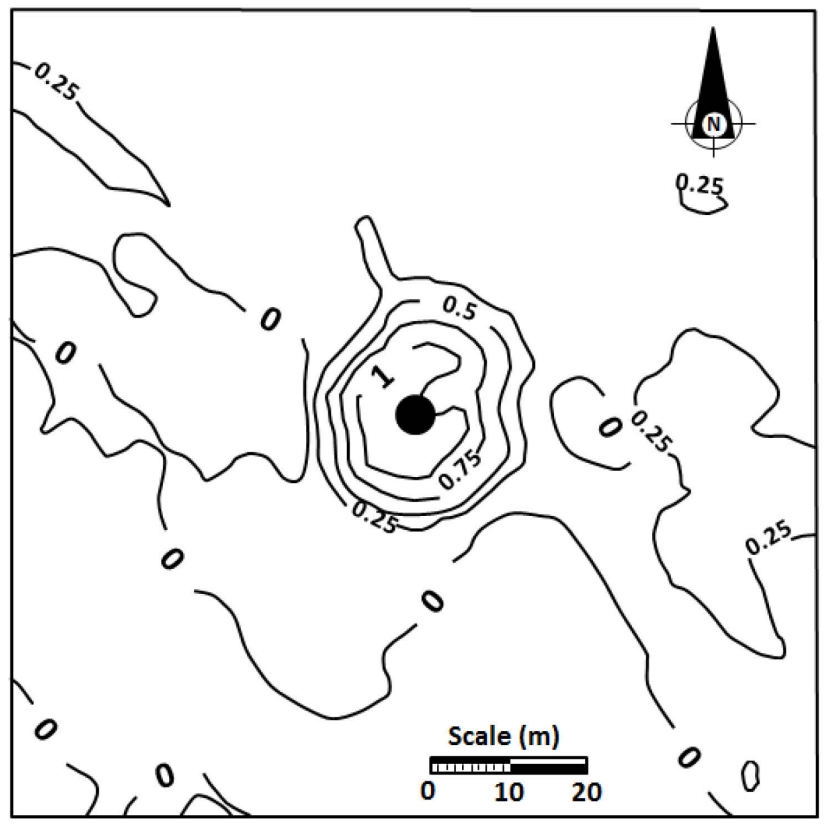

Figure 4. Example of measured scour hole in sand veneer overlying clay seabed at Barrow - scour contours at $0.25 \mathrm{~m}$ intervals below ambient bed level specified as $0 \mathrm{~m}$

\subsection{Kentish Flats OWF}

Kentish Flats OWF is located in the outer Thames Estuary, approximately $9 \mathrm{~km}$ off the north Kent coast. The seabed is generally flat and subtly varied comprising mainly coarse sand, but with varying amounts of shell gravel and small exposures of the underlying clay. Geotechnical surveys also showed the seabed to consist of variable thickness of sand underlain by soft to firm clays overlying London Clay formation. From the last available monitoring data at the wind farm site $S / D$ values of up to 0.4 were obtained. In the initial monitoring surveys, depressions were measured at four of the thirty $5 \mathrm{~m}$ diameter turbine foundations in January 2005 , some three months after completion. It is uncertain whether the initial "scour" depression around the turbines is due to hydraulic scour processes, or whether it was caused by "drawdown" of the soil during foundation installation or a combination of the two processes. The monitoring data also revealed depressions in the seabed in response to where the jack-up barge legs had been present during installation, most probably mainly due to penetration of the legs into the soil rather than through scour processes (see Figure 5). 
Assuming the scouring is the principal cause of the depressions at the foundations, the maximum measured depth was less than $0.28 \mathrm{D}$ in January 2005, increasing to $0.46 \mathrm{D}$ in November 2005 and decreasing again to 0.34D in April 2006. The picture of change was complex as the scour at one location increased with time during the three surveys whereas the scour at the other three locations increased in the first two surveys and then decreased in the last survey. Assuming consistency of the surveys, and the time variations were not an artefact arising from survey error, this suggested that seabed sediment transport processes were able to produce fluctuations in the depth of the scour around the foundations at this site. Figure 5 shows the scour development at Turbine E2 as measured in January 2005. The scour depth is around $0.8 \mathrm{~m}$ giving an $S / D$ ratio of 0.16 . It is interesting to note that the spudcan depressions to the southwest of the monopile location have a maximum depth of about $1.4 \mathrm{~m}$.

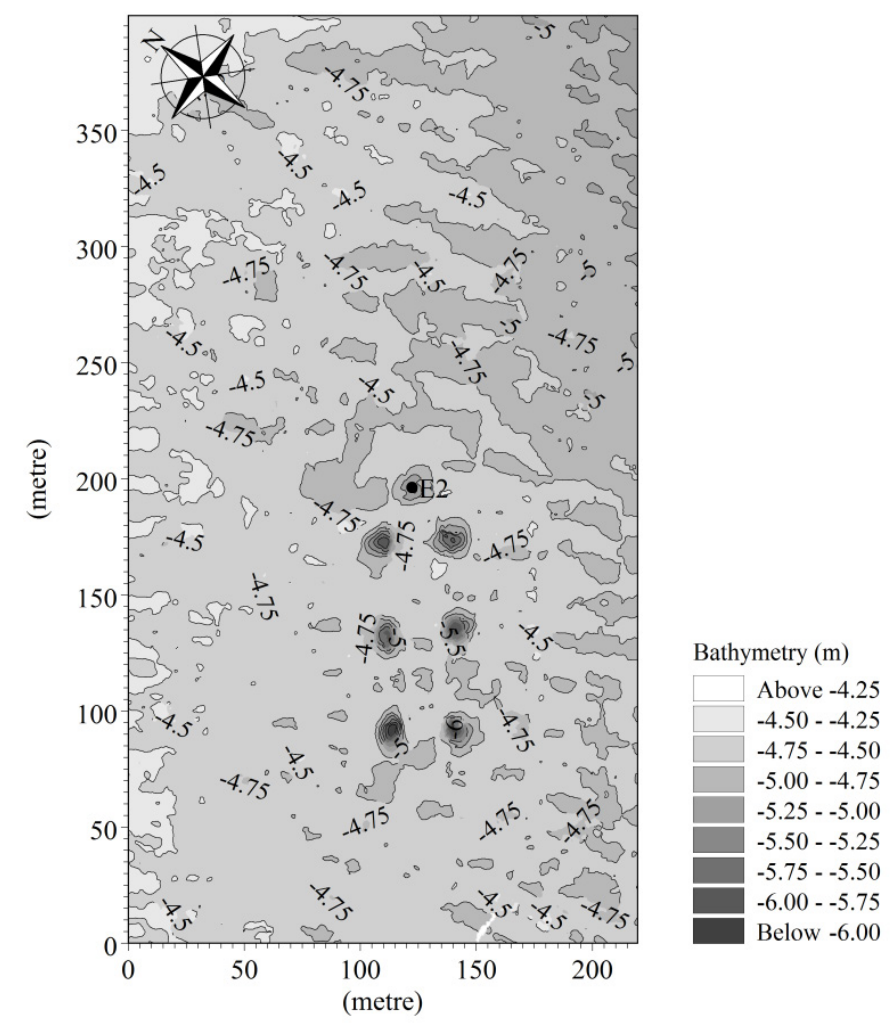

Figure 5. Scour development at turbine E2, Kentish Flats OWF survey, January 2005. Note jack-up spudcan depressions to southwest of monopile. (Data collected by EMU Ltd)

\subsection{North Hoyle OWF}

North Hoyle OWF is located about $7.5 \mathrm{~km}$ from the north Wales coast offshore of Rhyl. Within the wind farm site the seabed sediments generally consist of sandy gravel or gravelly sand with larger patches of gravel found further offshore. Within these areas the gravels tend to exist as thin veneer overlying sand or boulder clay. Results from various surveys shows the site as being strongly heterogeneous, having variability over very short distances and composed of very poorly sorted sediments. The thirty turbine foundations were installed over the period April to July 2003. Monitoring of the seabed post-installation was carried out over the period August to October 2004. 
Some limited scour (less than $0.125 \mathrm{D}$ ) was recorded in the 2004 survey at ten of the thirty foundations. In a survey conducted in April-May 2005 no scour was recorded at any of the foundations. No scour protection material was placed around the foundations although there was some redistribution of drill cuttings on the seabed which had arisen during the drill-drive process used to install the foundations. Burial of the inter-array cables was successful with target burial depths achieved in all but about $3 \%$ of the total cable runs. Where full burial was not achieved, rock protection was placed during 2004.

Figure 6. shows an example of the survey data for North Hoyle OWF. A mound of drill arisings can be observed to the southeast of the monopile. There is little evidence of scour development at the foundation.

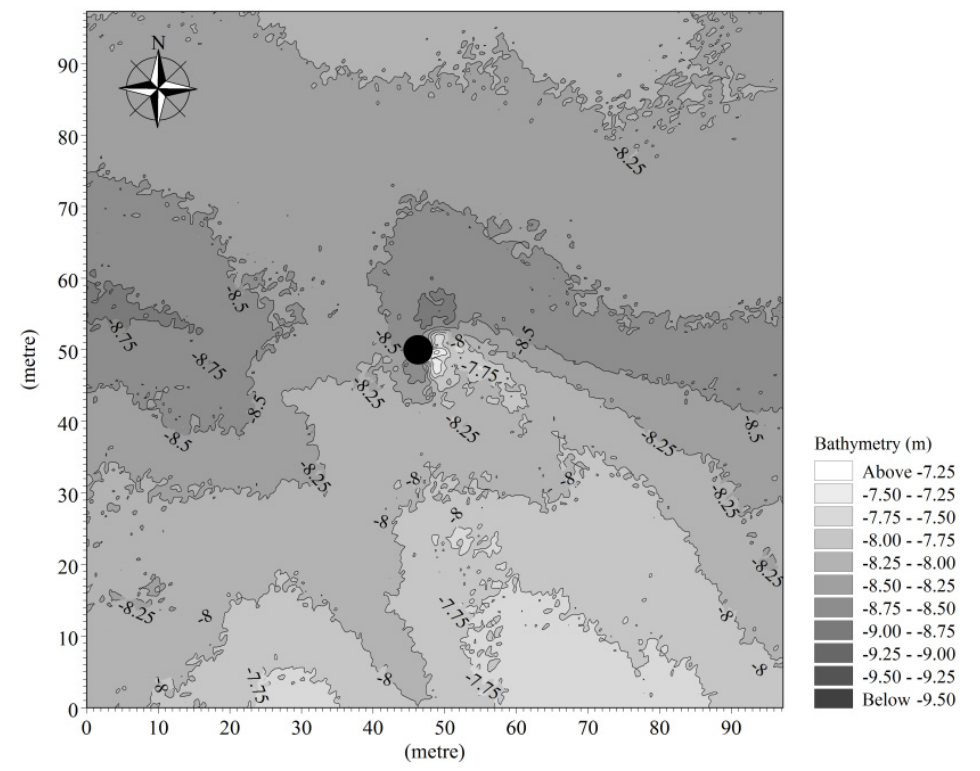

Figure 6. North Hoyle OWF measured bathymetry at turbine 10, survey 2005

\subsection{Scour evolution through time}

Scour development around offshore structures is primarily a function of the hydrodynamics, sedimentology and geotechnical properties at a site. Under tidal flows the current reverses direction with the phase of the tide and, therefore, scour development will take place, typically, in two directions. The time variation in scour depth corresponding to the time of installation of the foundation structure and the monitoring survey(s) is important as there will be a general increase in the scour depth to some equilibrium condition over a timescale that is site specific. In non-uniform soils it is possible that the equilibrium condition is not achieved over the (design) life of the project and, hence, having a reliable estimate of the time-scale in these type of soils is, arguably, of more importance than that in uniform non-cohesive soils. The time evolution of scour in offshore sites with non-uniform soils is more difficult to ascertain from available data due to the limited number of surveys available in time and the more gradual scour development. From the monitoring data for Round 1 wind farm sites (Barrow and Kentish Flats) the evidence base, as mentioned earlier, suggests a scour depth that is variable in time and spatially between different locations (Figure 7). The results show a general growth in scour but also reductions in scour depth from one survey to the next. However, inferring a general reduction in scour depth over time from this data should be cautioned against as this may just be a function of the prevailing conditions at the time of the survey rather than some longer-term trend. 


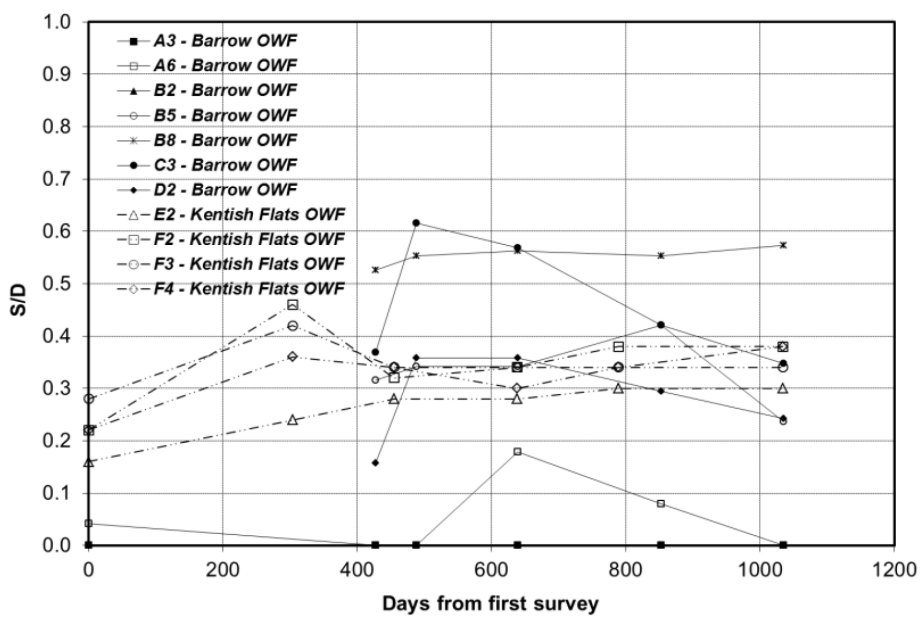

Figure 7. Variation of dimensionless scour depth with time at Barrow and Kentish Flats offshore wind farms

\section{The challenge}

The requirement to undertake a scour hazard assessment for offshore projects that involve large volume installation of foundations, such as those related to offshore wind farm developments, will inevitably mean that there is a limit to the amount of detailed geotechnical information that can be collected as part of the project beyond the key requirements for foundation design and in cable corridors. Therefore, there is a need to have a reliable scour predictor for a range of ground conditions. Harris et al. (2010) undertook an initial assessment of the Erodibility Index approach for a number of case studies offshore. The approach of Annandale $(1995 ; 2006)$ was used to assess the scour potential at three contrasting offshore locations. The principal attraction of the Erodibility Index method is that it allows for the physical properties of the soil to be considered and although the method does not directly take into account the chemical properties of the material, the mass strength number, $M_{S}$, represents the relative influence of chemical bonding properties of the soil through the unconfined compressive strength. In principal, the method represents an engineering methodology that can be applied using information obtained during geotechnical site investigations. However, to apply the approach to a given location requires a number of key considerations which include:

- The requirement for good information on the soil properties with depth through the seabed, including grain size distributions, density, undrained shear strength, internal angle of friction, etc from the seabed surface to the depth (at least) of $S_{\max }$, the maximum anticipated scour depth.

- Knowledge of the metocean conditions for both typical and extreme events.

Furthermore, the method relies on previously calibrated formulae for the stream power at the seabed and its variation with depth into the scour hole. There is still a requirement to determine the development of scour through time in complex marine soils and this requires further research, especially for soils with multi-modal grading distributions and with distinct layering. It is also important to determine any adjustment to soil properties that might occur during foundation installation that could affect resistance to scouring and the effects of abrasion by granular sediments is still not well understood (see Section 5). 
The key assumption in the Erodibility Index approach is that undrained shear strength can be used as a proxy for the erodibility of soil. What do we know already? Experimental evidence from the laboratory suggests that in general:

- as water content increases the scour depth increases;

n scour depth decreases with compaction (density) of cohesive soil, although heavy overconsolidation may reduce erosion resistance;

- scour depth increases with increasing Froude No.; and,

- scour depth decreases with increasing clay content.

Therefore, erosion is highly dependent on the degree of consolidation and moisture content and hydrodynamic conditions.

There is also evidence to suggest that erosion of cohesive soils may be controlled by the size of the particles rather than the properties of the cohesive soils in environments were the flows contain mobile non-cohesive granular particles and shelly material.

Using available data from a range of offshore sites and laboratory test data where suitable geotechnical properties are available, it is possible to assess whether the data supports the hypothesis that undrained shear strength can be used as a proxy for the erodibility of soil. Figure 8 presents an initial review of the various data shown as dimensionless scour depth $(S / D)$ against undrained shear strength.

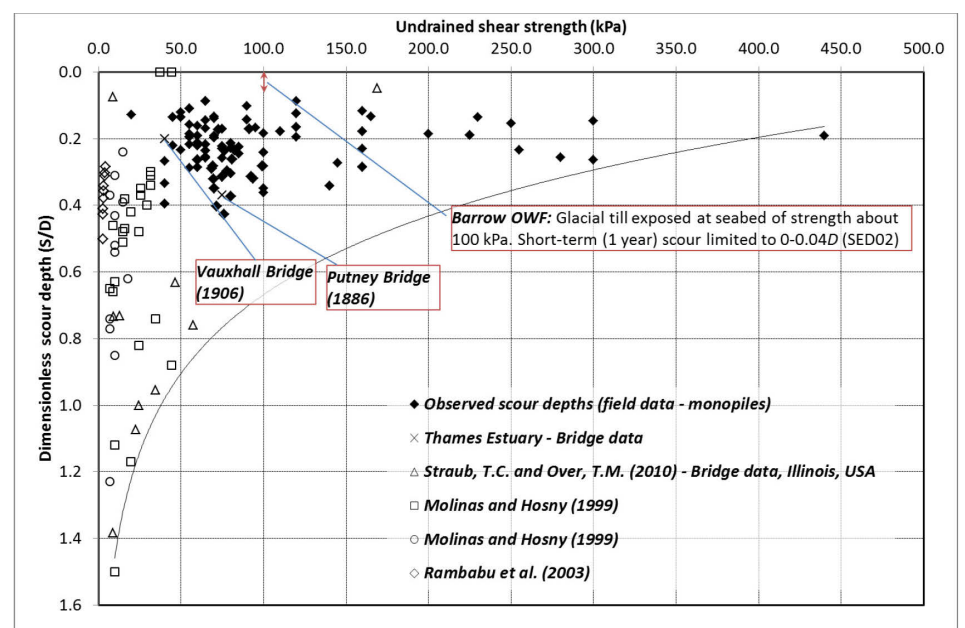

\section{Figure 8. Field and laboratory evidence base of scour depth against undrained shear strength}

The curve plotted in Figure 8 represents an envelope encompassing all the data only and is not intended to represent a curve fit. There is a significant amount of scatter within the data. There is an inherent limitation with the laboratory data as these data represent relatively low strength soils compared with those obtained from the majority of the field sites. The exception is the bridge scour data presented by Straub and Over (2010), which is in a similar range of soil strengths to those of the laboratory tests.

There are a number of difficulties with the field data including the representation of the layering effect of the marine soils. By this we mean that in the majority of cases the depth at which the scour has currently developed to has been achieved through eroding through a number of different soil strata with different properties. A decision was made to take the properties of the soil strata to which scouring has currently reached, but this may be somewhat arbitrary given the possible effects that the overlying layer(s) may have 
on the erodibility of the underlying soil layer. The values of undrained shear strength represent a preconstruction state and it is unknown what if any change in soil properties may have occurred during and post-installation of the structure, for example due to piling. In addition, the results do not have any temporal element and, therefore, may only be representative of a transient state, and the equilibrium scour depth has yet to be achieved. The exception is for the two bridge sites in the tidal River Thames (Vauxhall and Putney Bridges), which lie within the scatter of other data.

Comparing the results from the field with the Erodibility Index method as proposed by Annandale (2006) suggests that the method is not always conservative (Figure 9). It should be noted that Figure 9 represents only a subset of the data shown in Figure 8.

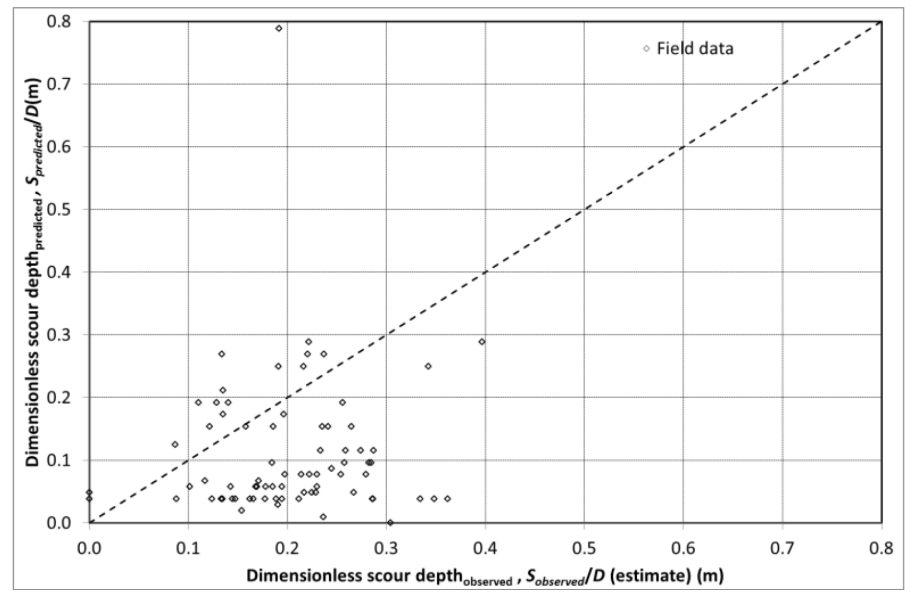

\section{Figure 9. Comparison of predicted scour depth (Erodibility Index method) against measured scour depth}

It should be noted, however, that in previous studies that have made use of the Erodibility Index method they have had access to detailed soil analysis including erodibility testing. This is not a feasible option for large volume installation projects were hundreds of foundations are being installed over an area of tens of kilometres. Therefore, there may be a requirement to recalibrate the approach based on the evidence base from the field. Where possible we would recommend some specific testing of soil erosion to increase confidence in scour estimates in non-uniform soils (Whitehouse and Harris, 2014).

\section{Conclusions}

Based on analysis of the available field and laboratory data a number of conclusions have been made and these are presented below:

- A range of soil parameters have been used in previous literature as a proxy for resistance to erosion and hence scour potential. The majority of these have been based on laboratory data and are untested with field observations. Evidence from field and laboratory measurements suggests undrained shear strength can be used as a proxy for the erodibility of soil.

- The Erodibility Index method (e.g. Annandale, 2006) is still one of very few approaches available to assess scour potential that combines both geotechnical properties and hydrodynamic forcing.

- The relationship may not follow that proposed by Annandale for circular piles. 
- Use of the methodology as presented by Annandale (2006) may not give conservative answers in the marine environment. However, it should be noted that previous use of the Erodibility Index method have used results from detailed soil analysis including erodibility testing.

- The results require further careful analysis through consideration of both geotechnical and hydrodynamic properties combined with knowledge of how the installation of the foundation may change soil properties.

- Better monitoring of in-situ structures and large-scale laboratory testing will improve the evidence base. Where possible we recommend this is combined with erosion testing.

\section{References}

Annandale, G.W. (1995). Erodibility. Journal of Hydraulic Research, 33 (4), 471-494.

Annandale, G.W. (2006). Scour Technology. Mechanics and Engineering Practice. McGraw-Hill.

Ansari, S.A., Kothyari, U.C. and Ranga Raju, K.G. (2002). Influence of cohesion on scour around bridge piers. J. Hydr. Res., Vol. 40, No. 6, pp. $717-729$.

Briaud, J-L., Ting, C.K., Chen, H.C., Gudavalli, R., Perugu, S. and Wei, G. (1999). SRICOS: Prediction of scour rate in cohesive soils at bridge piers. J. of Geotechnical and Geoenvironmental Engng., Vol. 125, No. 4, April, ASCE, pp. $237-246$.

Briaud, J.-L., Ting, F.C.K., Chen, H.C., Cao, Y., Han, S.W. and Kwak, K.W. (2001). Erosion function apparatus for scour rate predictions. J.I of Geotechnical and Geoenvironmental Engineering, 127, pp. 105-113.

COWRIE (2010). A Further Review of Sediment Monitoring Data. Final Report prepared by ABPmer Ltd, HR Wallingford Ltd and CEFAS for the Research Advisory Group, Project Ref. ScourSed-09, March, 115 p.

Debnath, K. and Chaudhuri, S. (2010). Laboratory experiments on local scour around cylinder for clay and clay-sand mixed beds. Engng. Geology, 111, Elsevier, pp. 51 -61.

Debnath, K. and Chaudhuri, S. (2012). Local scour around non-circular piers in clay-sand mixed cohesive sediment beds. Engng. Geology, 151, Technical Note, Elsevier, pp. 1 -14.

DECC (2008). Dynamics of scour pits and scour protection - Synthesis report and recommendations (Milestones 2 and 3). Final Report prepared by HR Wallingford Ltd, ABP Marine Environmental Research Ltd and Centre for Environment, Fisheries and Aquaculture Science for the Research Advisory Group, Department of Energy and Climate Change (DECC) and Department for Environment, Food and Rural Affairs (Defra).

Harris, J.M, Whitehouse, R.J.S. and Sutherland, J. (2010). Scour Assessment in Complex Marine Soils - An Evaluation through Case Examples. Proceedings Fifth International Conference on Scour and Erosion, Holiday Inn Golden Gateway, San Francisco, California, Nov. 7 -10.

Harris, J.M., Whitehouse, R.J.S. and Sutherland, J. (2011). Marine scour and offshore wind - lessons learnt and future challenges. Proceedings of the ASME 2011 30th International Conference on Ocean, Offshore and Arctic Engineering, OMAE2011, June 19-24, 2011, Rotterdam, The Netherlands, OMAE2011-50117.

Jiang, J., Ganju, N.K and Mehta, A.J. (2004). Estimation of contraction scour in riverbed using SERF. Journal of Waterway, Port, Coastal, and Ocean Engineering, 130, pp. 215-218. 
Mitchener, H.J., Whitehouse, R.J.S., Soulsby, R.L. and Lawford, V.A. (1996). Development of SedErode Instrument for In-Situ mud erosion measurements. Report TR17, HR Wallingford, 17pp (+tables and figures). Kamphuis, J.W. (1983). On the erosion of consolidated clay material by a fluid containing sand. Can. J. Civ. Eng., 10, pp. $223-231$.

Kamphuis, J.W., Gaskin, P.N. and Hoogendoorn, E. (1990). Erosion tests on four intact Ontario clays. Can. Geotech. J., 27, pp. $692-696$.

Kamphuis, J.W. and Hall, K.R. (1983). Cohesive material erosion by unidirectional current. J. Hydr. Eng., Vol. 109, No. 1, January, ASCE, pp. $49-61$.

Kothyari, U.C., Kumar, A. and Jain, R.K. (2014). Influence of cohesion on river bed scour in the wake region of piers. J. Hydr. Eng., Vol. 140, No. 1, January, ASCE, pp. $1-13$.

Lefebvre, G., Rohan, K. and Milette, J-P. (1986). Erosivity of intact clay: Influence of the natural structure. Can. Geotech. J., 23, pp. $427-434$.

Molinas, A., Jones, S. and Hosny, M. (1999). Effects of Cohesive Material Properties on Local Scour Around Piers, J. of the Transportation Research Board, Transportation Research Record, No. 1690, National Academy Press, pp. 164-175.

Rambabu, M., Narasimha Rao, S. and Sundar, V. (2003). Current-induced scour around a vertical pile in cohesive soil. Ocean Engng., 30, Elsevier, pp. 893 - 920.

Shen, H.W., Schneider, V.R. and Karaki, S.S. (1969). Local scour around bridge piers. J of the Hydraulics Div., Vol. 96, HY6, ASCE, pp. 1919 - 1940.

Straub, T.D. and Over, T.M. (2010). Pier and contraction scour prediction in cohesive soils at selected bridges in Illinois. Research Report ICT-10-074, Illinois Department of Transportation, August, 119 pp.

Terzaghi, K., Peck, R.B. and Mesri, G. (1996). Soil mechanics in engineering practice. $3^{\text {rd }}$ Edition, John Wiley \& Sons Inc., 592 pp.

Van Ledden, M., van Kesteren, W.G.M. and Winterwerp, J.C. (2004). A conceptual framework for the erosion behaviour of sand-mud mixtures. Continental Shelf Res., 24, pp. $1-11$.

Williamson, H.J. and Ockenden, M.C. (1996). ISIS - an instrument for measuring erosion stress in-situ. Estuarine, Coastal and Shelf Science, Vol. 42, 1-1.

Whitehouse, R.J.S. and Harris, J.M. (2014). Scour prediction offshore and soil erosion testing. Proceedings of the ASME $201433^{\text {rd }}$ International Conference on Ocean, Offshore and Arctic Engineering, OMAE2014, June 8-13, 2014, San Francisco, California, USA. Paper OMAE2014-24271.

Whitehouse, R.J.S., Harris, J.M., Sutherland, J. and Rees, J. (2010). The nature of scour development and scour protection at offshore windfarm foundations. Mar. Pollut. Bull., doi:10.1016 /j.marpolbul.2010.09.007.

Whitehouse R.J.S., Soulsby R.L., Roberts W., and Mitchener H.J. (2000). Dynamics of estuarine muds. Thomas Telford.

Winterwerp, J.C. and van Kesteren, W.G.M. (2004). Introduction to the physics of cohesive sediment in the marine environment. Elsevier. 